in Cases 4 and 5 where involvement of intertriginous areas simulated candidiasis, and also in Cases 3, 13, and 14 where nonflexural skin became involved. An extreme degree of this artificially boosted virulence is exemplified by Cases 7 and 11, where $T$. rubrum invaded hair follicles to cause kerion and folliculitis. This fungus has very rarely been implicated in kerion formation. The local action of corticosteroid preparations in producing striae distensae in sites of application is well recognized (Epstein, Epstein, and Epstein, 1963 ; Meara, 1964), and Case 9 is an example of this reaction.

Case 10 illustrates a feature that was seen in several of our patients which does not appear to have been described before and will be the subject of a fuller communication (Munro, 1968). The affected area in these patients showed atrophy and telangiectasia without scaling, giving the skin a translucent and poikilodermatous appearance. In Case 12 this occurred on the arm and gave rise to extreme diagnostic difficulty, but in Cases $1,3,6$, and 10 groin involvement suggested the correct diagnosis.

Hypopigmentation was seen in both coloured patients (Cases 1 and 14). This phenomenon does not usually follow resolution of ringworm after orthodox treatment and was confusing in Case 14, where a diagnosis of leprosy was initially entertained.

Case 13 was seen by several dermatologists before the correct diagnosis was made. The micropapules on her face were more suggestive of a type of rosacea than ringworm, and only the recognition of modified tinea elsewhere on her body suggested the correct diagnosis.

In the present context the old adage of diagnosis before treatment is probably impracticable in most general practices. It should be more widely known that skin scrapings may be taken for mycological examination as easily as bacteriological swabs. None the less it is likely that cases of masked ringworm will continue to occur. In our opinion the best form of prophylaxis is an increased awareness of tinea, especially in cases of groin and unilateral hand eruptions.

We wish to thank the consultants of St. John's Hospital for Diseases of the Skin, Dr. R. Marten and Dr. E. L. Rhodes, for details of patients under their care. We are indebted to Dr. Y. Clayton and the Department of Mycology at St. John's for the mycological investigations.

\section{REFERENCES}

Canizares, O., Shatin, H., and Kellert, A. J. (1959). Arch. Derm., 80, 705.

Cawson, R. A. (1968). Brit. med. Y., 1, 86.

Epstein, N. N., Epstein, W. L., and Epstein, J. H. (1963). Arch. Derm., 87,450 .

Grice, K. (for F. R. Bettley) (1966). Proc. roy. Soc. Med., 59, 254

Kligman, A. M. Baldridge, G. D., Rebell, G., and Pillsbury, D. M (1951). \%. Lab. clin. Med., 37, 615.

Meara, R. H. (1964). Brit. F. Derm., 76, 481

Meara, R. H. (1964). Brit. F. Derm., 76,
Munro, D. D. (1968). In preparation.

Pillsbury, D. M., Shelley, W. B., and Kligman, A. M. (1956). Dermatology, chap. 12, p. 106 . Philadelphia.

\title{
Lead Poisoning in Blind Children
}

\author{
A. C. AMES,* M.B., B.S., B.SC., M.C.PATH. ; P. N. SWIFT, $†$ M.R.C.P.
}

\begin{abstract}
Cummary : Many partially sighted children use the mouth, lips, and tongue as an aid in identifying objects-this has been termed discriminatory pica. Investigation of a case of lead poisoning in a pupil at a residential school for the blind led to the discovery of others with asymptomatic lead poisoning, all of whom had the same habit.

All the children recovered without treatment when they abandoned their habit of discrimination by use of the mouth. Authorities responsible for schools for the blind should be aware of this risk.
\end{abstract}

\section{Introduction}

The occurrence of symptomatic lead encephalopathy in one pupil at a residential school for the blind induced us to investigate other clinically normal pupils for lead intoxication. Several of these were found to have raised blood lead levels. We report the findings of the survey carried out at the school to identify the lead source and discuss their implications in the training and supervision of blind children.

\section{Case Report}

A boy aged 7 years who is partially blind on account of bilateral congenital cataracts was referred to the hospital outpatient clinic

\footnotetext{
- Senior Registrar in Chemical Pathology ; Lewisham Hospital, London S.E.13.

tConsultant Paediatrician, Farnborough, Orpington, and Sevenoaks Hospitals, Kent.
}

in March 1967 because of a history of periodic tingling in his tongue and a "funny feeling" in his head over a period of several months. He had recently suffered two major epileptic seizures.

On physical examination no relevant abnormality was detected and the skull $x$-ray picture was normal. On 15 March the haemoglobin was $84 \%$ (12.5 g. $/ 100 \mathrm{ml}$.), E.S.R. $2 \mathrm{~mm}$. in one hour (Westergren), total W.B.C. count 5,000/cu. mm., blood sugar $76 \mathrm{mg} . / 100 \mathrm{ml}$. , and blood lead $116 \mu \mathrm{g} . / 100 \mathrm{ml}$. (normal range $<35 \mu \mathrm{g} . / 100 \mathrm{ml}$.).

Penicillamine $600 \mathrm{mg}$. daily was given for 42 days (total $25.2 \mathrm{~g}$.). Repeat blood lead on 21 April was $50 \mu \mathrm{g} . / 100 \mathrm{ml}$. and on 18 December $33 \mu \mathrm{g} . / 100 \mathrm{ml}$.

Progress.-Anticonvulsant therapy (phenobarbitone $30 \mathrm{mg}$. b.d.) was maintained, but three further major seizures occurred four months after his course of penicillamine. Since August he has remained well. Questioning about possible sources of lead ingestion revealed that he was in the habit of chewing everything from toys to radio components. Furthermore, he utilized lip and tongue sensation to identify objects and assess their texture. It seems that the exploratory pica so often found in young children and well developed in this patient had gone beyond this stage as an additional sensory mechanism performing a useful function. We differentiate this acquired form of pica by the term "discriminatory pica." He also used algebra and arithmetic type composed of metal stated by the manufacturers to contain $65 \%$ lead, $25 \%$ antimony, and $10 \%$ tin. Each type has raised dots on one face and a raised bar on the other face, which when set at different angles in a frame represents different numbers. This boy used the tongue to identify each type before placing it in the frame.

\section{Survey to Detect Other Cases of Lead Poisoning}

After the recognition of the first case 10 pupils were selected on the basis of their having a history of discriminatory pica, 
as it was thought that further cases of lead-poisoning might be found in this group. Eight of these children used the arithmetic type. Blood lead levels were estimated by the method of Moncrieff et al. (1964), and the results are shown in Table I.

TABLE I.-Blood Lead Levels in Group of Children with Discriminatory

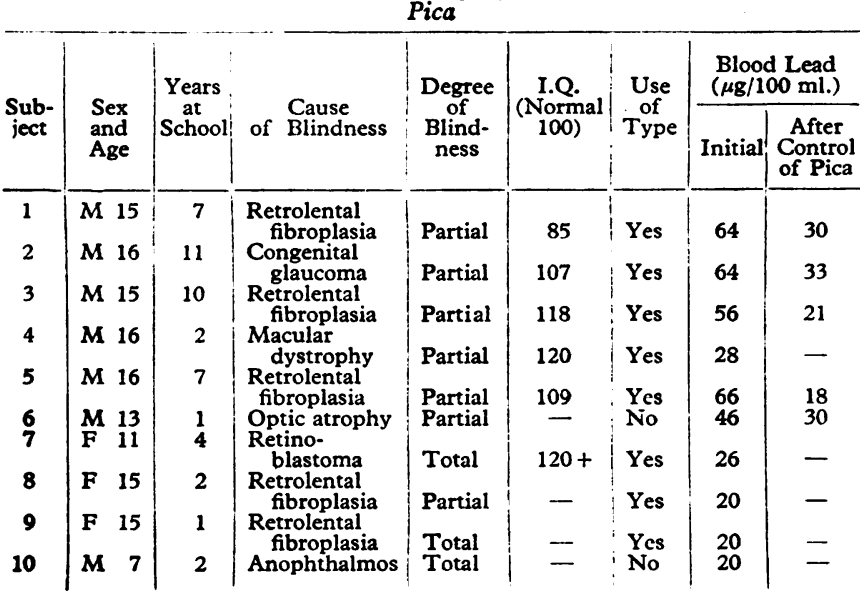

Those children whose blood lead was raised were not deleaded with chelating agents, but were asked to refrain from licking the type and putting objects in their mouths. They were keen to co-operate, for the situation had been explained. Four months later blood lead estimations were repeated.

TABLE II.-Results From Control Group of Residential Adults and Pupils Without Pica Chosen at Random

\begin{tabular}{|c|c|c|c|c|c|c|}
\hline & Sex & $\underset{(\%)}{\mathrm{Hb}}$ & P.C.V. & M.C.H.C. & $\begin{array}{c}\text { Punctate } \\
\text { Basophilia }\end{array}$ & $\underset{(\mu \mathrm{g} . / 100 \mathrm{ml} .)}{\text { Blood Lead }}$ \\
\hline $\begin{array}{c}\text { Control } \\
\text { group } \\
\text { (adults): } \\
1 \\
2 \\
3 \\
4 \\
5 \\
6 \\
7 \\
8\end{array}$ & $\begin{array}{c}\mathbf{F} \\
\mathbf{F} \\
\mathbf{F} \\
\mathbf{F} \\
\mathbf{F} \\
\mathbf{M} \\
\underset{\mathbf{F}}{\mathbf{F}}\end{array}$ & $\begin{array}{r}88 \\
92 \\
81 \\
102 \\
90 \\
107 \\
100 \\
87\end{array}$ & $\begin{array}{l}41 \\
41 \\
40 \\
45 \\
40 \\
46 \\
44 \\
40\end{array}$ & $\begin{array}{l}31 \\
33 \\
30 \\
33 \\
33 \\
32 \\
33 \\
32\end{array}$ & $\begin{array}{l}\text { Absent } \\
\text { Absent } \\
\text { Absent } \\
\text { Absent } \\
\text { Absent } \\
\text { Absent } \\
\text { Absent } \\
\text { Absent }\end{array}$ & $\begin{array}{l}27 \\
18 \\
15 \\
21 \\
16 \\
16 \\
18 \\
29\end{array}$ \\
\hline $\begin{array}{c}\text { Random } \\
\text { pupils } \\
\text { (no pica): } \\
1 \\
2 \\
3 \\
4 \\
5 \\
6 \\
7 \\
8 \\
9 \\
10 \\
11 \\
12 \\
13 \\
14 \\
15 \\
16\end{array}$ & $\begin{array}{l}\mathbf{F} \\
\mathbf{F} \\
\mathbf{F} \\
\mathbf{F} \\
\mathbf{F} \\
\mathbf{F} \\
\mathbf{F} \\
\mathbf{F} \\
\mathbf{M} \\
\mathbf{M} \\
\mathbf{M} \\
\mathbf{M} \\
\mathbf{M} \\
\mathbf{M} \\
\mathbf{M} \\
\mathbf{M}\end{array}$ & $\begin{array}{r}100 \\
88 \\
78 \\
93 \\
87 \\
97 \\
101 \\
94 \\
97 \\
105 \\
99 \\
92 \\
90 \\
95 \\
105 \\
95\end{array}$ & $\begin{array}{l}44 \\
41 \\
37 \\
41 \\
40 \\
44 \\
43 \\
42 \\
43 \\
47 \\
44 \\
41 \\
41 \\
42 \\
47 \\
44\end{array}$ & $\begin{array}{l}33 \\
31 \\
31 \\
33 \\
32 \\
32 \\
34 \\
33 \\
33 \\
33 \\
33 \\
33 \\
32 \\
33 \\
33 \\
31\end{array}$ & $\begin{array}{l}\text { Absent } \\
\text { Absent } \\
\text { Absent } \\
\text { Absent } \\
\text { Absent } \\
\text { Absent } \\
\text { Absent } \\
\text { Absent } \\
\text { Absent } \\
\text { Absent } \\
\text { Absent } \\
\text { Absent } \\
\text { Absent } \\
\text { Absent } \\
\text { Absent } \\
\text { Absent }\end{array}$ & $\begin{array}{l}18 \\
18 \\
34 \\
28 \\
6 \\
27 \\
19 \\
25 \\
19 \\
22 \\
19 \\
12 \\
19 \\
13 \\
27 \\
25\end{array}$ \\
\hline
\end{tabular}

A further 16 pupils, none of whom gave a history of pica and who had not used arithmetic type, were taken at random. Haemoglobin, P.C.V., M.C.H.C., and blood lead were determined and a blood film was screened for punctate basophilia. A second control group of eight normal adults who had been resident at the school for many years (nursing sister, teachers, etc.) were similarly investigated. The results are shown in Table II.

\section{Results}

Five of the 10 children with discriminatory pica (Table I) had a raised blood lead level, the upper limit of normal being taken as $35 \mu \mathrm{g} . / 100 \mathrm{ml}$. They were all asymptomatic. Three had used the arithmetic type for many years and one for one year, the average duration of exposure being 7.2 years. After the period when their pica was controlled all the blood leads had fallen to below $35 \mu \mathrm{g} . / 100 \mathrm{ml}$. Of the remaining five children with normal blood leads four who used type had been at the school only a year or two and had used type for a much shorter period, the average duration of use by this group being less than 2.2 years. All members of the control group had normal blood leads and no haematological abnormality, which indicates that there is unlikely to be a common source of the lead-namely, in the water supply or cooking utensils, etc.

Of the 16 pupils taken at random only one girl (No. 3) with a haemoglobin of $78 \%$ and blood lead of $34 \mu \mathrm{g} . / 100 \mathrm{ml}$., but otherwise asymptomatic, was suspected of suffering from mild lead intoxication, but a repeat blood lead estimation fell well within the normal range.

\section{Discussion}

When a case of lead encephalopathy and a number of other cases showing a raised blood lead occur in a closed community like this boarding school a thorough search for the source of the lead is essential.

The school had been repainted recently, but there was no evidence that paintwork had been chewed. The glaze used in the pottery class was lead-free and none of the children had been observed to eat dirt or putty or to have ordinary pica. The results from the control group are taken to indicate that there is no central source of lead in the school.

Moncrieff et al. (1964) and Gibson et al. (1967) have drawn attention to the association of lead-poisoning, pica, and mental retardation. None of the pupils in the discriminatory pica group were mentally retarded, and the I.Q.s where they were available confirm this.

Totally blind children rely mainly on the sense of touch to identify objects in their environment, but many of the partially sighted who can differentiate light from dark or just read print do not develop the same highly developed sense of touch. Consequently they use the mouth, the lips, and the tongue in addition for identification purposes-that is, discriminatory pica. It was in this group of partially sighted children with discriminatory pica, and only in this group, that the cases with raised blood lead were found. They all used lead-containing type and had had long exposure to this source, but were asymptomatic. Because the blood lead levels had returned to normal after this discriminatory pica had been discouraged by the school authorities, without any form of active treatment, there is a strong inference that lead was being ingested in this way.

The use of lead type for arithmetic purposes is being replaced in schools for the blind by an abacus system. None of the pupils included in the "random control group" had used lead type, and they had already been introduced to the new system. The presence of one child (Subject 6) with a raised blood lead, but who had not used type, indicates that it is still possible to ingest lead from other sources by this habit of discriminatory pica. In order to prevent lead-poisoning in other schools for the blind we suggest that the authorities should be alert to the dangers inherent in the presence of leadcontaining objects and that their pupils be dissuaded from the habit of discriminatory pica wherever possible.

We thank Dr. A. H. W. Roffey for permission to investigate patients under his care and the headmaster for his help and co-operation.

\section{REFERENCES}

Gibson, Sheila L. M., Lam, C. N., McCrae, W. M., and Goldberg, A. (1967). Arch. Dis. Childh., 42, 573.

Moncrieff, A. A., Koumides, O. P., Clayton, Barbara E., Patrick, A. D. Renwick, A. G. C., and Roberts, G. E. (1964). Arch. Dis. Childh. 39. 1 . 